\title{
Uptake of Americium and Plutonium from Contaminated Sediments by Three Benthic Species: Arenicola marina, Corophium volutator and Scrobicularia plana
}

\author{
P. Miramand, P. Germain and H. Camus \\ Commissariat à l'Energie Atomique, I.P.S.N., DPr-SERE, Laboratoire de Radioécologie Marine, B.P. 270, F-50107 Cherbourg, \\ France
}

\begin{abstract}
The biological availability of americium $\left({ }^{241} \mathrm{Am}\right)$ and plutonium $\left({ }^{238} \mathrm{Pu}\right)$ contained in a muddy sediment was investigated in 3 burrowing coastal benthic species: the polychaete annelid Arenicola marina (L.), the bivalve mollusc Scrobicularia plana (da Costa) and the amphipod crustacean Corophium volutator (Pallas). The biological availability was expressed in terms of a transfer factor defined as the activity in the organisms $\left(\mathrm{cpm} \mathrm{g}^{-1}\right.$ wet weight) relative to the activity in the sediment $\left(\mathrm{cpm} \mathrm{g}{ }^{-1}\right.$ wet weight). For the 3 species and both radionuclides, the transfer factors observed were low $(<1)$ after $14 \mathrm{~d}$ in contact with the contaminated sediment. Uptake by $C$. volutator $(\mathrm{TF}=0.1)$ was 10 times $(\mathrm{TF}=0.01)$ and 50 times $(\mathrm{TF}=0.002)$ greater than uptake by $S$. plana and $A$. marina respectively. A comparative investigation of the biological availability of americium and plutonium contained in seawater showed, for the same exposure period, that the concentration in the organism relative to the concentration in the water (C.F.) was about 1000 for americium and 780 for plutonium in C. volutator, but much lower for the other 2 species. The data obtained demonstrate that part of the americium transferred to the organisms comes from the sediment's interstitial water. Part of the americium retained by the animals could therefore result from direct transfer from sedimentary particles to organisms.
\end{abstract}

\section{INTRODUCTION}

Numerous studies on the biogeochemistry of transuranic elements in marine environments indicate that ultimately most of the plutonium and americium deposited in the ocean from atmospheric fallout or wastes from nuclear industries is transferred to the sediments (Noshkin and Bowen, 1973; Hetherington et al., 1975; 1976; Livingston and Bowen, 1976a, b; Ballestra, 1980; and references therein). However, it appears that the transuranic elements contained in the solid wastes that might be emplaced within deep-sea sediments, would also be concentrated in the sediments over a long period of time (Sousselier, 1977; Talbert, 1977). Recent investigations show that, once they are adsorbed, these transuranic elements are not irreversibly retained on the sedimentary particles but obey the fundamental distribution law. Thus they can be released on contact with interstitial and surface waters which contain lower concentrations than required by the mass action constant for the reaction (Noshkin and Wong, 1980;
Pentreath et al., 1980). The problem is to understand the biological availability of these radionuclides for benthic species living in contact with the sediment. To our knowledge, all experimental studies on the uptake of plutonium and americium from sediments by benthic species have used only the polychaete worm Nereis diversicolor (Beasley and Fowler, 1976; Murray and Renfro, 1976). Thus studies should be developed to include other species representative of benthic indofauna and epifauna.

This paper deals with the results of experiments on the uptake of plutonium and americium from contaminated sediments by 3 coastal benthic species: the polychaete annelid Arenicola marina (L.), the bivalve mollusc Scrobicularia plana (da Costa), and the amphipod crustacean Corophium volutator (Pallas). These species live in sediments, or at the sediment-sea water interface, and belong to zoological groups which occur in deep water (Hessler and Sanders, 1967; Hessler and Jumars, 1977; Rice, 1978; Sibuet, 1979).

A first experiment (Experiment A) quantifies the 
transfer of these radionuclides from labelled sediment to organisms (T.F.), while a second experiment (Experiment B) studies the uptake from labelled seawater by the same organisms (C.F.).

\section{MATERIALS AND METHODS}

Corophium volutator were trapped on the shore neas the port of Saint Vaast-la-Hougue (eastern coast of Cotentin). Scrobicularia plana and Arenicola marina were collected from mud near the port of Ouistreham (Calvados).

The ${ }^{241} \mathrm{Am}$ (half-life: $434 \mathrm{y}$ ), ${ }^{239} \mathrm{Pu}$ (half-life: $24,386 \mathrm{y}$ ), and ${ }^{238} \mathrm{Pu}$ (half-life: $86 \mathrm{y}$ ), conditioned in $\mathrm{HNO}_{3} 1 \mathrm{~N}$ were obtained from the C.E.A. (France). Before use, ${ }^{239} \mathrm{Pu}$ and ${ }^{238} \mathrm{Pu}$, were put into a (VI) oxidation state according to Duursma and Parsi's method (1974). ${ }^{241} \mathrm{Am}$ is assumed to be in a (III) state.

The ${ }^{241}$ Am gamma ray (60 keV) was measured with $25 \%$ efficiency with a gamma spectrometer coupled to a Nal(TI) well crystal.

${ }^{239} \mathrm{Pu}$ and ${ }^{238} \mathrm{Pu}$ alpha emissions were counted by liquid scintillation spectrometry using Picofluor 15 as the scintillator. Before counting, the samples were pretreated as follows:

(1) After collection the individuals were rinsed, weighed, dissected ( $S$. plana) and then oven-dried for $48 \mathrm{~h}\left(\mathrm{~T}=95^{\circ} \mathrm{C}\right)$. The tissues were mineralised using hot $\mathrm{HNO}_{3}$ directly in the counting vials. After mineralisation, the $\mathrm{HNO}_{3}$ was removed by evaporation, the dry residue redissolved in $3 \mathrm{ml}$ of $\mathrm{HCl} 0.1 \mathrm{~N}$, and $15 \mathrm{ml}$ of scintillator was added.

(2) The radioactivity of $2 \mathrm{ml}$ of sea water from the experimental aquarium was directly counted in $15 \mathrm{ml}$ of scintillator.

(3) $5 \mathrm{~g}$ of dried sediment were calcined for $24 \mathrm{~h}$ at $600{ }^{\circ} \mathrm{C}$, then shaken for $24 \mathrm{~h}$, in a $50: 50$ mixture of $\mathrm{HCl}$ $-\mathrm{HNO}_{3}\left(200 \mathrm{ml} 80^{\circ} \mathrm{C}\right)$. The acid extraction was repeated. Numerous tests, we have realized, have demonstrated that about $96 \%$ of the plutonium in the sediments can be desorbed in this way. After centrifugation, aliquots of 50 and $100 \mu$ l of supernatants were directly placed in $15 \mathrm{ml}$ of scintillator and counted.

An external standard ratio calibration curve was plotted; the count yield was in all cases greater than $95 \%$.

\section{Accumulation from Sediment (Experiment A)}

Muddy sediment was collected at the same time as the Corophium volutator Table I shows how the sediment was prepared (sifting) and labelled with ${ }^{241} \mathrm{Am}$ and ${ }^{238} \mathrm{Pu}$. The sediment was labelled in such a way that the radionuclide concentration in sea water was always less than $10^{-8} \mathrm{M}$ in order to avoid any polymerization of these isotopes.

The animals were introduced into the sediment: 100 individuals weighing on average $0.015 \mathrm{~g}$ wet weight for the Corophium volutator, 15 individuals of around $3 \mathrm{~g}$ wet weight for the Arenicola marina and 8 individuals averaging $9 \mathrm{~g}$ wet weight for the Scrobicularia plana. The $14 \mathrm{~d}$ experiment was carried out under clean running sea water. After sampling, the individuals were placed in clean running sea water for $16 \mathrm{~h}$ to void their gut before preparation for analysis (vide supra), and were then carefully rinsed. Measuring the radioactivity in the organism as well as in the sediment makes it possible to calculate the transfer factor (T.F.): $\mathrm{cpm} \mathrm{g}^{-1}$ animal wet weight/ $\mathrm{cpm} \mathrm{g}^{-1}$ sediment wet weight.

After the biological uptake experiments the sediment was analysed to determine the binding strength of ${ }^{241} \mathrm{Am}$ to the sediment. Aliquot portions were extracted with acetic acid at $\mathrm{pH} 2$, and then with a 50:50 mixture of concentrate $\mathrm{HCl} \cdot \mathrm{HNO}_{3}$ at $80^{\circ} \mathrm{C}$. Interstitial water was extracted from two $600 \mathrm{~g}$ samples of sediment using a press similar to that described by Presley et al. (1967). The concentration of ${ }^{241} \mathrm{Am}$ in the interstitial water was then measured. As both the concentrations of radioactivity in the sediment (AS) and the interstitial water ( $A$ is w) are known, the distribution coefficient of ${ }^{241} \mathrm{Am}$ between the sediment and its interstitial water ( $K d=A S / A$ is w) can be calculated.

Table 1. Scheme of contamination processes of sediments used in our experiments (dry to wet ratio $==0.41$ )

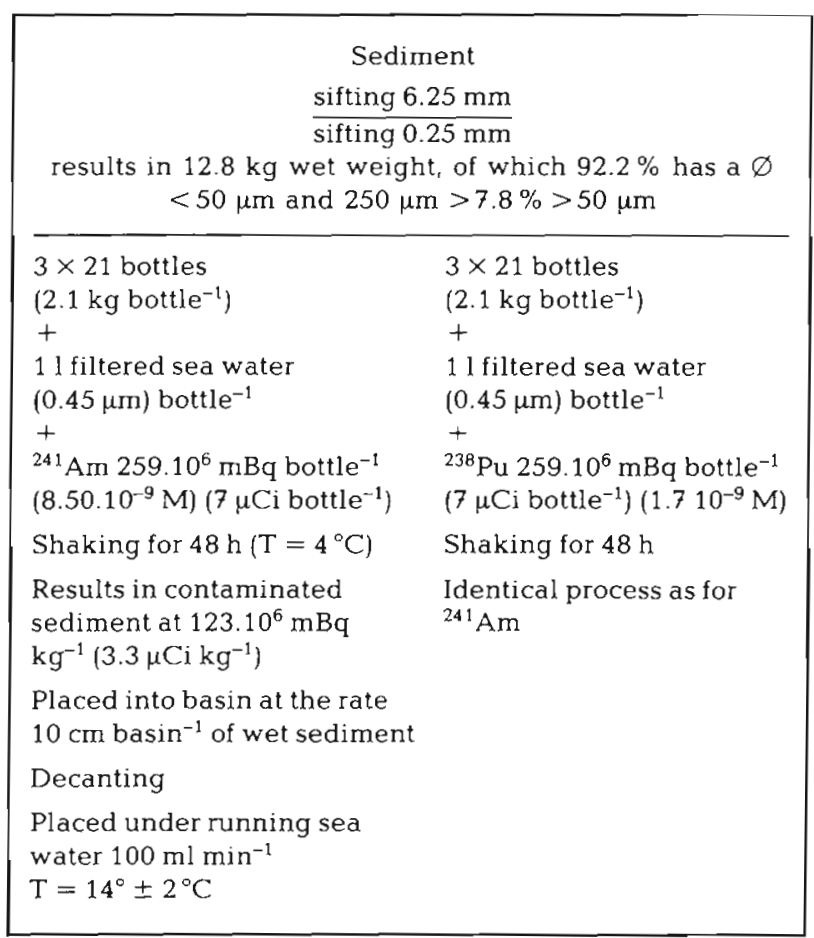




\section{Uptake from Sea Water (Experiment B)}

For each isotope, 100 Corophium volutator, 30 Arenicola marina, and 30 Scrobicularia plana, all weighing the same as those used previously, were placed individually in plastic aquaria containing $20 \mathrm{ml}$ (C. volutator and $200 \mathrm{ml}$ A. marina and S. plana) of sea water filtered on a millipore filter $(0.45 \mu \mathrm{m})$, at $14^{\circ} \mathrm{C}$. subsequently, $6475 \mathrm{mBq} \mathrm{ml}^{-1}\left(175 \mathrm{pCi} \mathrm{ml}^{-1}\right)$ for ${ }^{241} \mathrm{Am}$, and $1776 \mathrm{mBq} \mathrm{ml}^{-1}\left(48 \mathrm{pCi} \mathrm{ml} l^{-1}\right)$ for ${ }^{239} \mathrm{Pu}$ were added. The sea water was changed every $48 \mathrm{~h}$ using water of the same quality containing the same concentrations of radioisotopes. Each time the water was changed 10

Table 2. Percentage of ${ }^{241}$ Am desorbed by 2 successive acid attacks on the contaminated sediment and percentage, before acid extraction, of ${ }^{241} \mathrm{Am}$ retained on the contaminated sediment fractions smaller or larger than $50 \mu \mathrm{m}$

\begin{tabular}{|cccc|}
\hline \multicolumn{2}{|c|}{ Extract (\%) } & \multicolumn{2}{c|}{ Activity (\%) } \\
$\begin{array}{c}\text { Acetic acid } \\
\mathrm{pH} 2\end{array}$ & $\begin{array}{c}\mathrm{HCl-HNO} \mathrm{HN}_{3} \\
80^{\circ} \mathrm{C}\end{array}$ & $\begin{array}{c}\text { Particles of } \\
\varnothing>50 \mu \mathrm{m}\end{array}$ & $\begin{array}{c}\text { Particles of } \\
\varnothing<50 \mu \mathrm{m}\end{array}$ \\
\hline 66 & 31 & 8.6 & 91.4 \\
\hline
\end{tabular}

individuals ( $C$. volutator) and 4 individuals ( $A$. marina and $S$. plana) were collected as well as aliquots from the new and old solutions for analysis. Counting their radioactivity made it possible to calculate the concentration factor defined as $\mathrm{cpm} \mathrm{g}^{-1}$ animal wet weight/ cpm $\mathrm{ml}^{-1}$ sea water.

\section{RESULTS}

For the 2 extractions, the ${ }^{241} \mathrm{Am}$ activity of the contaminated sediment-interstitial water was around $7.4 \mathrm{mBq} \mathrm{ml}^{-1}\left(0.2 \mathrm{pCi} \mathrm{ml}^{-1}\right)$. The sediment-interstitial water $\mathrm{Kd}$ obtained from this value was $5.10^{4}$. It is interesting to note as well that $91 \%$ of the element was attached to sedimentary particles of less than $50 \mu \mathrm{m}$ in diameter and that $66 \%$ of the ${ }^{241} \mathrm{Am}$ could easily be desorbed from the sediment by acetic acid at $\mathrm{pH} 2$ (Table 2).

The transfer factors of ${ }^{241}$ Am to the Corophium volutator, Scrobicularia plana, and Arenicola marina obtained at the end of Experiment A were low, less than 1 (Table 3). This was also true for plutonium whose transfer factors were the same as for americium

Table 3. Transfer factor of ${ }^{241} \mathrm{Am}$ and ${ }^{238} \mathrm{Pu}$ from contaminated sediment to Corophium volutator, Arenicola marina and Scrobicularia plana. $\mathrm{T}=14{ }^{\circ} \mathrm{C}$. Radionuclide concentrations in sediment $\left(\mathrm{cpm} \mathrm{g}{ }^{-1}\right.$ wet weight): ${ }^{238} \mathrm{Pu}=8828 ;{ }^{241} \mathrm{Am}=2276 / \mathrm{dry}$ to wet ratio: sediment $=0.41 ;$ Corophium volutator $=0.19 ;$ Arenicola marina $=0.14 ;$ Scrobicularia plana, entire $=0.41$, soft part $=0.07$, shell $=0.86$

\begin{tabular}{|c|c|c|c|c|c|}
\hline Species & Radioisotope & $\begin{array}{c}\text { Duration of } \\
\text { experiments (d) }\end{array}$ & $\begin{array}{l}\text { Number of } \\
\text { individuals }\end{array}$ & $\begin{array}{c}\text { cpm g }^{-1} \\
\text { wet weight }\end{array}$ & $\begin{array}{c}\text { Transfer } \\
\text { factor }\end{array}$ \\
\hline \multicolumn{6}{|c|}{ Corophium volutator } \\
\hline & ${ }^{241} \mathrm{Am}$ & 4 & 60 & 228 & 0.10 \\
\hline & ${ }^{241} \mathrm{Am}$ & 14 & 14 & 273 & 0.12 \\
\hline & ${ }^{238} \mathrm{Pu}$ & 4 & 14 & 883 & 0.10 \\
\hline & ${ }^{238} \mathrm{Pu}$ & 14 & 21 & 883 & 0.10 \\
\hline \multicolumn{6}{|l|}{ Arenicola marina } \\
\hline & ${ }^{241} \mathrm{Am}$ & 6 & 8 & 4.55 & 0.002 \\
\hline & ${ }^{241} \mathrm{Am}$ & 14 & 4 & 6.83 & 0.003 \\
\hline & ${ }^{238} \mathrm{Pu}$ & 6 & 8 & 17.66 & 0.002 \\
\hline & ${ }^{238} \mathrm{Pu}$ & 14 & 4 & 17.66 & 0.002 \\
\hline \multicolumn{6}{|l|}{ Scrobicularia plana } \\
\hline \multirow[t]{4}{*}{ Entire } & ${ }^{241} \mathrm{Am}$ & 7 & 4 & 15.93 & 0.007 \\
\hline & ${ }^{241} \mathrm{Am}$ & 14 & 4 & 20.48 & 0.009 \\
\hline & ${ }^{238} \mathrm{Pu}$ & 7 & 4 & 88.28 & 0.01 \\
\hline & ${ }^{238} \mathrm{Pu}$ & 14 & 4 & 88.28 & 0.01 \\
\hline \multirow[t]{4}{*}{ Soft part } & ${ }^{241} \mathrm{Am}$ & 7 & 4 & 13.66 & 0.006 \\
\hline & ${ }^{241} \mathrm{Am}$ & 14 & 4 & 22.76 & 0.01 \\
\hline & ${ }^{238} \mathrm{Pu}$ & 7 & 4 & 79.45 & 0.009 \\
\hline & ${ }^{238} \mathrm{Pu}$ & 14 & 4 & 44.14 & 0.005 \\
\hline \multirow[t]{4}{*}{ Shell } & ${ }^{241} \mathrm{Am}$ & 7 & 4 & 15.93 & 0.007 \\
\hline & ${ }^{241} \mathrm{Am}$ & 14 & 4 & 22.76 & 0.01 \\
\hline & ${ }^{238} \mathrm{Pu}$ & 7 & 4 & 88.28 & 0.01 \\
\hline & ${ }^{238} \mathrm{Pu}$ & 14 & 4 & 88.28 & 0.01 \\
\hline \multirow[t]{4}{*}{ Pallial fluid } & ${ }^{241} \mathrm{Am}$ & 7 & 4 & 11.38 & 0.005 \\
\hline & ${ }^{241} \mathrm{Am}$ & 14 & 4 & 4.55 & 0.002 \\
\hline & ${ }^{238} \mathrm{Pu}$ & 7 & 4 & 17.66 & 0.002 \\
\hline & ${ }^{238} \mathrm{Pu}$ & 14 & 4 & 26.48 & 0.003 \\
\hline
\end{tabular}


(Table 3). However, differences in uptake of the 2 transuranic elements by the 3 benthic species tested can be observed: $C$. volutator (T.F. $=0.1$ ) accumulated about 10 times more of the transuranic elements from the contaminated sediment than did $S$. plana (T.F. $\approx 0.01$ ) and 50 times more than $A$. marina $(T . F . \simeq 0.002$ ). These differences were also found for the concentration factors from labelled sea water in Experiment B (Fig. 1, 2, 3). For the same time period in the labelled water, viz. $12 \mathrm{~d}, C$. volutator accumulated 10 times more americium (C.F. $\simeq 1000$ ) and 14 times more plutonium (C.F. $\approx 780$ ) than $S$. plana (whole) and 78 times more americium and 180 times more plutonium than A. marina.

For uptake from water (Experiment B), the 3 tested species preferentially accumulated americium rather than plutonium (Fig. 1, 2, 3). Scrobicularia plana shells accumulate a greater concentration of the 2 transuranic elements than do the soft part or the pallial fluid (Fig. 2); the soft part seems to be in isotopic equilibrium with the elements in the water from the 14 th day for ${ }^{239} \mathrm{Pu}$ and the 20th day for ${ }^{24 t}$ Am (Fig. 2). However, for the other $S$. plana tissues, as well as for Corophium

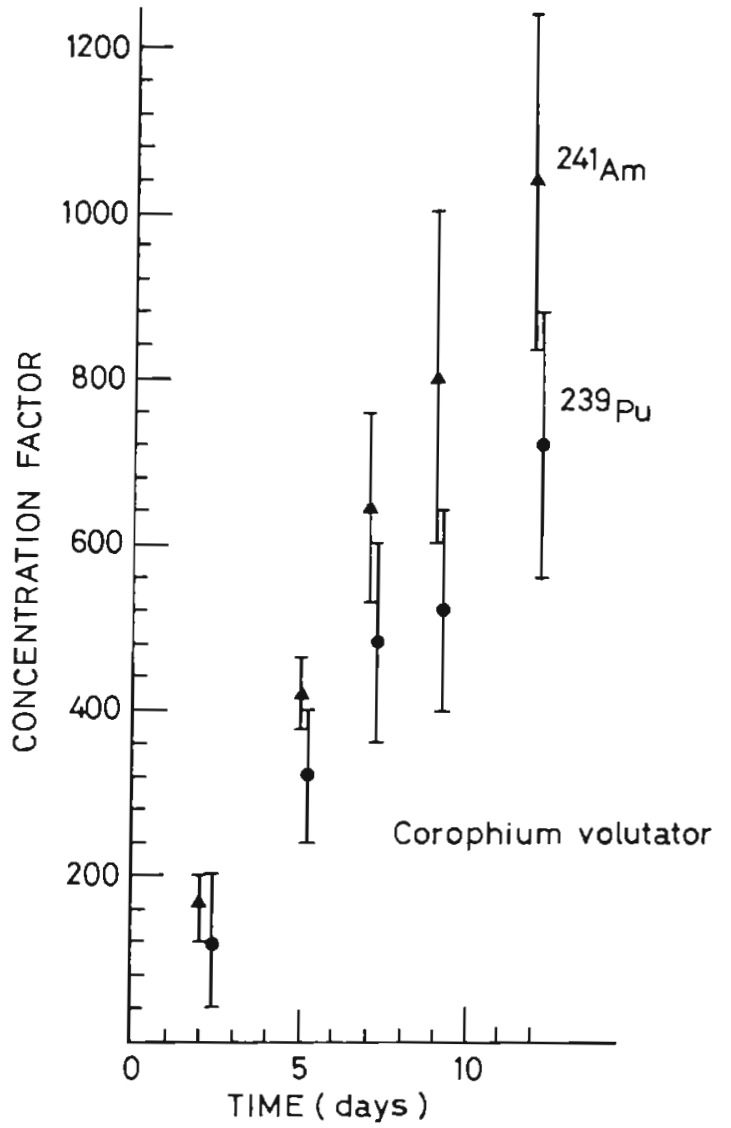

Fig. 1. Corophium volutator. Accumulation of ${ }^{241} \mathrm{Am}$ and ${ }^{239} \mathrm{Pu}$ from labelled sea water. $\mathrm{T}=14^{\circ} \mathrm{C}(\mathrm{n}=10$ per group, mean wet weight of 100 individuals $=0.015 \pm 0.005 \mathrm{~g}$ ) volutator, and Arenicola marina, the plutonium and americium accumulation remains linear at the end of the different periods of experimentation (Fig. 1, 2, 3).

Table 4 shows americium and plutonium distributions in various parts of Scrobicularia plana, after accumulation of these elements from labelled sea water (Experiment B) or contaminated sediment (Experiment $\mathrm{A}$ ). In both cases, the greatest percentage of americium and plutonium is found in the shells.

\section{DISCUSSION}

After 2 weeks of contact with the highly contaminated sediments, the radioactivity found in the 3 tested species, although measurable, is low. The animals voided their gut for $16 \mathrm{~h}$ under running sea water. However, in spite of this procedure, several residual grains of sediment could remain in the individuals, and because of their high activities, would falsify the measurement. In fact, the problem does not occur. For Corophium volutator the residual sediment weight should correspond to around $40 \%$ of the sample, and around $1.5 \%$ for Scrobicularia plana and Arenicola marina, i.e. from 30 to $140 \mathrm{mg}$ wet weight of sediment; however, when the animals are mineralized for plutonium measurement, once the organic matter is destroyed no trace of sedimentary particles is found in the samples. Our experiments demonstrate that americium and plutonium transfer from contaminated sediments does occur in C. volutator, A. marina, and $S$. plana. This transfer is low and varies with the species (from 0.1 for C. volutator to 0.002 for A. marina).

Our results for Arenicola marina confirm the transfers observed by Beasley and Fowler (1976) and by Murray and Renfro (1976), between Nereis diversicolor and various contaminated sediments (T.F. between $0.0015(\mathrm{Pu})$ and $0.0003(\mathrm{Am})$ ). Our data also show that other burrowing benthic species such as Scrobicularia plana and Corophium volutator can accumulate plutonium and americium from contaminated sediment from 5 to 50 times more, respectively, than the annelids.

It would seem that the transuranic elements retained on the sediment are only slightly accumulated by the benthic species, as already observed for certain heavy metals and fission products (Renfro, 1973: Ueda et al., 1977; 1978 Jennings and Fowler, 1980 and references therein).

The transfer of radionuclides from sediment to burrowing benthic species can take place in 2 ways: (1) direct uptake by desorption of the transuranic elements retained in the ingested sediment when passing through the digestive tract: (2) indirect uptake via interstitial water, i.e., simple water-organism 
Table 4. Scrobicularia plana. Tissue distribution of americium and plutonium following exposure to labelled sea water or contaminated sediment. $\mathrm{T}=14^{\circ} \mathrm{C}$ ( $\pm=$ standard deviation for 4 individuals)

\begin{tabular}{|c|c|c|c|c|c|}
\hline \multirow[t]{2}{*}{ Tissue } & \multicolumn{2}{|c|}{$\begin{array}{c}\% \text { Total } \\
\text { Americium content }\end{array}$} & \multicolumn{2}{|c|}{$\begin{array}{c}\text { \% Total } \\
\text { Plutonium content }\end{array}$} & \multirow[t]{2}{*}{$\begin{array}{l}\% \text { Total } \\
\text { Wet wt }\end{array}$} \\
\hline & $\begin{array}{c}\text { After } 32 \mathrm{~d} \\
\text { exposure to } \\
\text { labelled sea } \\
\text { water }\end{array}$ & $\begin{array}{c}\text { After } 14 \mathrm{~d} \\
\text { exposure to } \\
\text { contaminated } \\
\text { sediment }\end{array}$ & $\begin{array}{c}\text { After } 42 \mathrm{~d} \\
\text { exposure to } \\
\text { labelled sea } \\
\text { water }\end{array}$ & $\begin{array}{l}\text { After } 14 \mathrm{~d} \\
\text { exposure to } \\
\text { contaminated } \\
\text { sediment }\end{array}$ & \\
\hline Shell & $87 \pm 2$ & $58 \pm 5$ & $89 \pm 4$ & $66 \pm 18$ & $35 \pm 2$ \\
\hline Soft part & $12 \pm 3$ & $36 \pm 4$ & $9 \pm 3$ & $30 \pm 12$ & $34 \pm 3$ \\
\hline Pallial fluid & $1 \pm 1$ & $5 \pm 2$ & $1 \pm 1$ & $4 \pm 1$ & $34 \pm 2$ \\
\hline
\end{tabular}

Fig. 2. Scrobicularia plana. Accumulation of ${ }^{241} \mathrm{Am}$ and ${ }^{239} \mathrm{Pu}$ from labelled sea water. $\mathrm{T}=14^{\circ} \mathrm{C}(\mathrm{n}=4$ per group, mean wet weight of 60 individuals $=9 \pm 2 \mathrm{~g}$ )

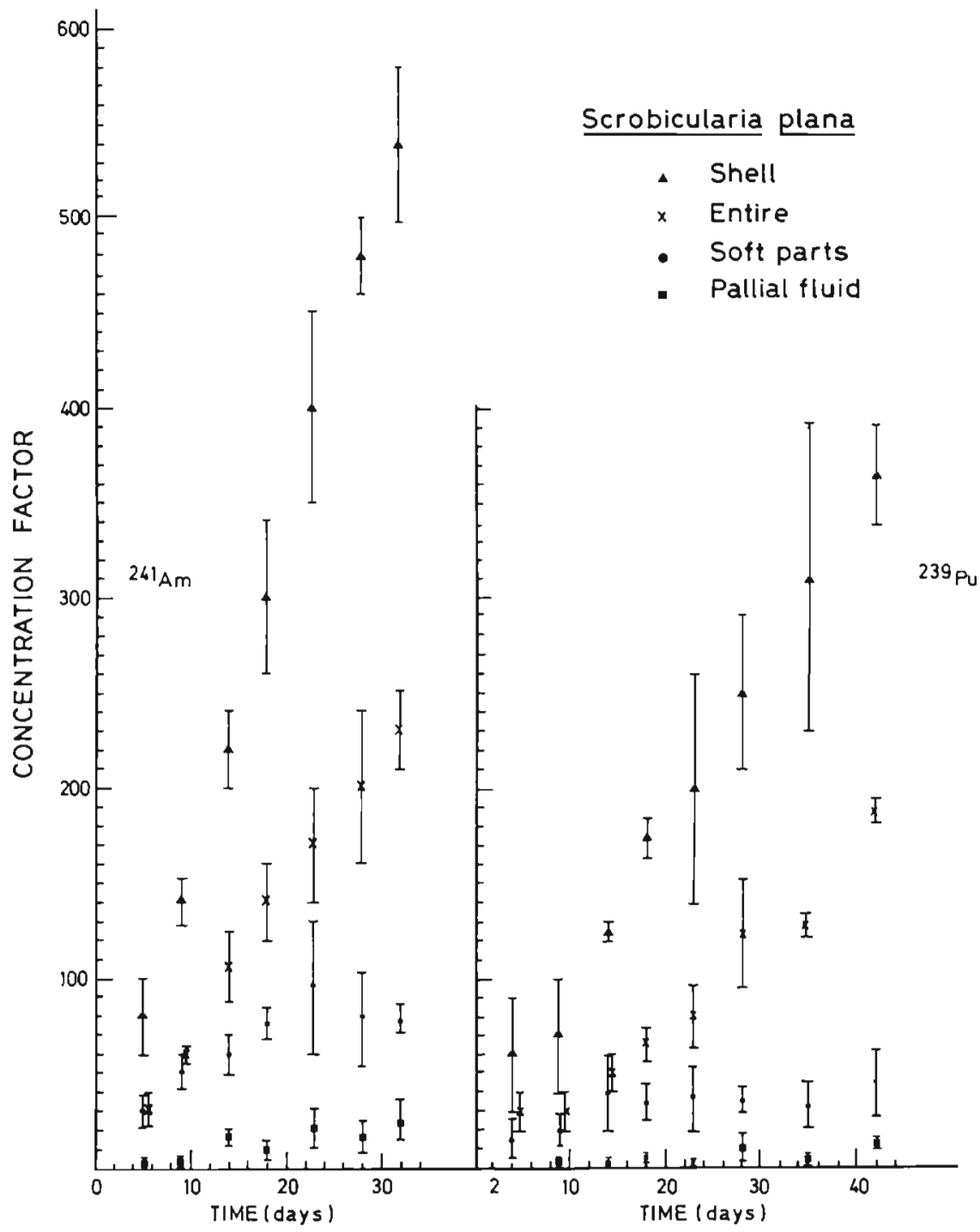

exchange. In our experiments with americium, we found low quantities of this element in the interstitial water of the sediment $\left(\simeq 0.2 \mathrm{pCi} \mathrm{ml}^{-1}\right)$. This allows the determination in Experiment A (transfer sedimentspecies) of the C.F. reached by the animals from the sediment's interstitial water, i.e. $C F$ isw. The ratio $C F_{i s w} / C F^{*}$ sw calculated for the same experimental

- $C F s w$ : Concentration factor found in Experiment B (uptake from labelled sea water) and reported in Figs. 1, 2 and 3 
Table 5. Comparison of $C F s w$ for americium found in Experiment B (uptake from labelled sea water) and $C F$ isw calculated from the value of interstitial sea water in Experiment A (transfer from labelled sediment)

\begin{tabular}{|lcccc}
\hline Species & $\begin{array}{c}C F \\
\text { from interstitial water } \\
\text { (CF isw) }\end{array}$ & $\begin{array}{c}C F \\
\text { from labelled sea water } \\
\text { (CFsw) }\end{array}$ & CF isw/CFsw \\
\hline Corophium volutator & & 2700 & 1200 & 2.3 \\
Arenicola marina & Soft part & 137 & 60 & 4.3 \\
& Shell & 228 & 220 & 2.3 \\
& & & 1.0 \\
\end{tabular}

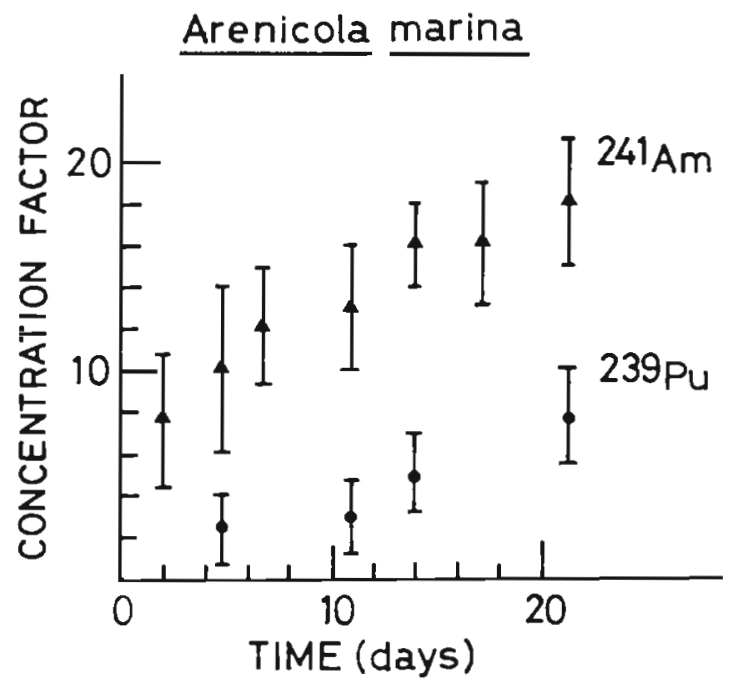

Fig. 3. Arenicola marina. Accumulation of ${ }^{241} \mathrm{Am}$ and ${ }^{239} \mathrm{Pu}$ from labelled sea water. $\mathrm{T}=14^{\circ} \mathrm{C}(\mathrm{n}=4$ per group, mean wet weight of 44 individuals $=3 \pm 1 \mathrm{~g}$ )

period (14 d) is greater than 1 (Table 5). Thus it would seem that the transfer of ${ }^{241} \mathrm{Am}$ (T.F.) observed in Experiment A cannot be exclusively explained by a simple interstitial water/organism exchange. Consequently, part of the americium taken up by the animals may be directly transferred from the sediment, probably by desorption of the americium in the ingested sediment.

All animals tested continuously ingested contaminated sediment. Corophium volutator can only ingest sedimentary particles with diameters between 4 and $63 \mu \mathrm{m}$ (Fenchel et al., 1975), and $92 \%$ of the experimental sedimentary particles had a diameter of less than $50 \mu \mathrm{m}$ and fixed more than about $91 \%$ of the radioactivity. Throughout the test, Arenicola marina burrowed into the sediment, and Scrobicularia plana inhaled surface sediment through the siphon. In any event, in spite of the continuous ingestion of highly contaminated sediments, the observed uptake was very low. The extractions of americium from the sediment by $\mathrm{pH} 2$ acetic acid, which indicate a $66 \%$ desorbtion of this element, do not seem to prove the bio-availability of this fraction.
Our experimental results show that benthic species can mobilize the transuranic elements within the biodisturbed layer. They demonstrate that the transfer of ${ }^{241} \mathrm{Am}$ sorbed on sediment to benthic species could occur through two different processes: (1) indirect transfer via interstitial water and (2) direct transfer from sediment to species. The transfer factors we measured in a short period seem to be low, but one cannot predict the effect of this pathway on the contamination of sea products reaching man. Such an effect could only be evaluated by means of specific transfer models including the data obtained in the present work. In both cases, within the limit of extrapolation of the experimental results obtained with the 3 coastal species belonging to zoological groups present in deep water, small amphipods would seem to represent a more significant dissemination vector for transuranic elements in the marine environment than bivalves or polychaetes

Acknowledgement. The authors wish to express their gratitude to Professor D.N. Edgington who constructively read and corrected the manuscript.

\section{LITERATURE CITED}

Ballestra, S. (1980). Radioactivité artificielle et environnement marin, étude relative aux transuraniens ${ }^{238} \mathrm{Pu}$ ${ }^{239}+{ }^{240} \mathrm{Pu}{ }^{241} \mathrm{Pu}$ et ${ }^{241}$ Am en Méditerranée. Thèse de Doctorat d'Etat (Sciences), Université de Nice

Beasley, T.M. Fowler, S.W. (1976). Plutonium and americium uptake from contaminated sediments by the polychaete Nereis diversicolor. Mar. Biol. 38: 95-100

Duursma, E.K., Parsi, P. (1974). Distribution coefficient of plutonium between sediment and sea water. In: Activities of the International Laboratory of Marine Radioactivity. International Atomic Energy Agency, Vienna, pp. 94-96.

Fenchel, T., Kofoed, L.H., Lappalainen, A. (1975). Particle size-selection of two deposit feeders: the amphipod Corophium volutator and the prosobranch Hydrobia ulvae. Mar Biol. 30: 119-128

Hessler, R. R., Jumars, P.A. (1977). Abyssal communities and radioactive waste disposal. Oceanis 20

Hessler, R. R., Sanders, H.L. (1967). Faunal diversity in the deep sea. Deep Sea Res. 14:65-78

Hetherington, J.A., Jefferies, D.F., Lovett, M.B. (1975). Some 
investigations into the behavior of plutonium in the marine environment. In. Impacts of nuclear releases into the aquatic environment. International Atomic Energy Agency, Vienna, pp. 193-212

Hetherington, J.A., Jefferies, D.F., Mitchell, N.J., Pentreath, R.J., Woodhead, D.S. (1976). Environmental consequences of the controlled disposal of transuranic elements to the marine environment. In: Transuranium nuclides in the environment. Intemational Atomic Energy Agency, Vienna, pp. 139-154

Jennings, C.D., Fowler, S.W. (1980). Uptake of ${ }^{55} \mathrm{Fe}$ from contaminated sediments by the polychaete Nereis diversicolor. Mar. Biol. 56: 277-280

Livingston, H. D., Bowen, V T (1976a). Americium in the marine environment: Relationships to plutonium. In: Miller, M. W., Stannard, J. W. (eds.) Environmental toxicity of aquatic radionuclides: Models and mechanisms. Ann Arbor Science, Ann Arbor, pp. 107-130

Livingston, H. D., Boven, V. T. (1976b). Contrast between the marine and freshwater biological interactions of plutonium and americium. Health and Safety Laboratory Report HASL-315, pp. 1-157

Murray, C. N., Renfro, W. C. (1976). Uptake of plutonium from sea water and a marine polychaete worm. J. oceanogr. Soc. Japan 32: 249-252

Noshkin, V E., Bowen, V. T. (1973). Concentrations and distribution of long-lived fallout radionuclides in open ocean sediments. In: Radioactive contamination of the marine environment. International Atomic Energy Agency, Vienna, pp. 671-686

Noshkin, V. E., Wong, K. M. (1980). Plutonium mobilization from sedimentary source to solution in the marine envi- ronment. In: Marine radioecology, Tokyo, 1-5 Oct, 1979 OCDE, Paris, pp. 165-178

Pentreath, R. J., Jefferies, D. F., Lovett, M. B., Nelson, D. M. (1980). The behaviour of transuranic and other longlived radionuclides in the lrish Sea and its relevance to the deep sea disposal of radioactive wastes. In: Marine radioecology, Tokyo, 1-5 Oct. 1979. OCDE, Paris, pp. 203-221

Presley, B. J., Brooks, R. R., Kappel, H. M. (1967). A simple squeezer for removal of interstitial water from ocean sediments. J. mar Res. 25: 355-357

Renfro, W. C. (1973). Transfer of ${ }^{65} \mathrm{Zn}$ from sediments by marine polychaete worms. Mar Biol. 21: 305-316

Rice, A. L. (1978). Radioactive waste disposal and deep-sea biology. Oceanol. Acta 4: 483-491

Sibuet, M. (1979). Connaissances générales sur les communautés benthiques abyssales dans l'Atlantique NordEst. Rapport CNEXO, COB, Brest, BT II/14047-D1

Sousselier, $Y$ (1977). Programme et réalisations françaises en matière de déchets. In: Proceedings of the technical seminar on the treatment, conditionning and storage of solid alpha-bearing waste and cladding halls. OCDE, Paris, pp. $29-33$

Talbert, D. M. (1977). Seabed disposal program, annual Report, Part I, January-December 1976. Sandia Laboratories Report SAND-77-1270

Ueda, T., Nakamura, R., Suzuki, Y (1977). Comparison of influence of sediments and sea water on accumulation of radionuclides by worms. J. Radiat. Res. 18: 84-92

Ueda, T., Nakamura, R., Suzuki, Y (1978). Comparison of influence of sediments and sea water on accumulation of radionuclides by marine organisms. J. Radiat. Res. 19: 93-99

This paper was presented by Dr. J. Mauchline; it was accepted for printing on September 8, 1981 